\title{
Prospective surveillance of healthcare associated infections in a haematology-oncology department
}

\author{
Nabiha Bouafia ${ }^{1,2,3}$, Asma Ammar ${ }^{1,2}$, Olfa Ezzi ${ }^{1,2}$, Asma Ben Cheikh ${ }^{4,2}$, Mohamed Mahjoub ${ }^{1,2}$, Wadiaa Bannour ${ }^{1}$, \\ Radhia Helali ${ }^{1}$, Arwa ben salah ${ }^{5}$,Bechir Achour ${ }^{6,2}$, Dalel Ben Slimane ${ }^{6}$, Abderrahim Khelif ${ }^{6,2}$, Mansour Njah ${ }^{1,2}$
}

${ }^{1}$ Hospital Hygiene Department, Farhat Hached university Hospital, Sousse, Tunisia ${ }^{2}$ Ibn Al Jazzar university of Medecine, Sousse University, Avenue Mohamed Karoui, Sousse, 4002, Tunisia,

${ }^{3}$ Infection Prevention and Control Department, King Faycal medical complex, Taief, Saudi Arabia

${ }^{4}$ Department of Prevention and Safety care, Sahloul University hospital - Sousse, Tunisia

${ }^{5}$ Department of Epidemiology and Preventive Medicine, University Hospital of Monastir

${ }^{6}$ Clinical Hematology service, University Hospital. Farhat Hached, Sousse, Tunisia

\begin{abstract}
In haematology-oncology, intensified procedures have been associated with higher risk of healthcare associated infections (HAls).This study aimed to estimate the incidence and to identify risk factors of HAls in a haematology-oncology unit in a Tunisian university hospital. We conducted a prospective study, during 6 months from March through September 2016 in the department of haematology-oncology in a tertiary teaching hospital in Tunisia. Patients, admitted for $\geq 48 \mathrm{~h}$, were followed until hospital discharge. The CDC criteria for site-specific infections were used to define HAls. Bivariate and multivariate analyses were performed to identify risk factors of HAls. A p value $<0.05$ was considered as significant. A total of 150 patients were included in this study with mean age $23.12 \pm 18.36$ years. The overall rate of HAls was $32.6 / 100$ patients with an incidence 15.7 per 1000 patient-days at risk. Nosocomial fever of unknown origin was the most frequent infection (42.9\% of total HAI's). Independent risk factors for developing HAls were male gender $(\mathrm{OR}[\mathrm{Cl}] 95 \%=4.60[1.43-14.61] ; \mathrm{p}=0.01)$, neutropenia $(\mathrm{OR}[\mathrm{Cl}] 95 \%=10.20[2.26-45.72], \mathrm{p}=0.002)$, aplasia inducing chemotherapy $(\mathrm{OR}[\mathrm{Cl}] 95 \%=6.0$ [1.07-33.19], $\mathrm{p}=0.004)$ and bone marrow aspiration and biopsy $(\mathrm{OR}[\mathrm{Cl}] 95 \%=3.0$ [1.10-8.03], $\mathrm{p}=0.03)$. In conclusion, our study highlights the burden of HAls in this unit and the role of surveillance for specific HAls and analyzing its risk factors. A comprehensive education program focused on evidence-based approaches for all healthcare workers should be implemented in this unit.
\end{abstract}

Keywords: healthcare associated infections, haematology, surveillance, risk factors, Tunisia.

\section{Corresponding Author}

Asma Ammar

Hospital Hygiene Department

Farhat Hached University Hospital

4002 Sousse, Tunisia

Email: asmamedcom@gmail.com 


\section{Background}

Over the past few decades, major progress has been made in the curative treatment of haematological malignancies which has resulted in reduced overall mortality. ${ }^{1}$ This improvement has allowed increasingly aggressive management in diagnostic and therapeutic procedures. ${ }^{2}$ chemotherapy, bone marrow or peripheral blood stem cell transplantation. This could lead to severe and prolonged immunosuppression, increasing the risk of healthcare-associated infections (HAIs) and possibly worsening the prognosis. ${ }^{3} \mathrm{HAls}$ are important adverse events in the disease history of patients with haematological malignancies, sometimes culminating in death; they are also responsible for longer hospital stay and increased healthcare costs. ${ }^{4}$

The occurrence of HAls differs in different patient populations and different hospitals. ${ }^{2}$ However, few studies have examined the incidence of HAls in this patient population as most surveillance has focused only on bone marrow transplant patients or children. ${ }^{3}$ In our tertiary teaching hospital, a HAls surveillance program was implemented since 2000. In 2009, the incidence of serious adverse events including HAls in medical departments was $13.7 \% .^{5}$ Since 2016 , a large prospective surveillance program was launched in several departments by the infection control department, and to our knowledge this is the first prospective study conducted in the haematologyoncology unit aiming specifically to evaluate HAIs.

The objectives of this study were:

- To assess HAls incidence among patients with neoplastic diseases in a tertiary teaching hospital.

- To identify the common etiological pathogens for these infections.

- To identify the independent risk factors for these infections as a first step toward improving infection control policies in this unit.

\section{Methods}

\section{Setting and patients}

An observational prospective study, based on active surveillance for a period of 6 months from March through September 2016, was undertaken in the haematology-oncology unit of Farhat Hached teaching hospital of Sousse. This ward has a 28-bed capacity and has been recently renovated. All patients admitted to the unit were monitored for HAls from admission until discharge from the unit; no active post-discharge surveillance was performed. All patients were screened daily by haematologists assisted by an infection control physician using a pretested and standardized survey record. Patients from day hospital were excluded.

\section{Data collection}

The following data were collected:

- Patient characteristics: age, sex, weight, size, medical history life habits, previous hospitalizations' history, and immune status.

- Current hospitalization related data: date of admission and discharge, mode of admission, sector of admission (protective isolation or conventional hospitalization), reason for hospitalization, antibiotics prior to the admission, underlying disease, admission and discharge diagnosis, laboratory test results (routine blood tests), and mode of discharge. We defined neutropenia as absolute neutrophil count $<0.5 \times$ $\left.10^{9} / \mathrm{L}\right)^{6}$

- Invasive procedures used and their duration (intubation, urinary catheterization, peripheral or central venous catheterization, nasogastric tube, parenteral nutrition, implantable venous access port, bone marrow aspiration and biopsy, lumber puncture)

- HAI-related data for each suspected HAI: specific clinical data, documented signs and symptoms, and direct observation were used to identify possible HAls. Source materials included medical records, temperature charts, information from nursing and medical staff, and results of microbiological testing. Once an HAI was confirmed, therapeutic interventions, and clinical course of the infectious episode were recorded.

Cultures from blood, urine, bronchial secretions, and from any other site with clinical suspicion of infection were performed based on the judgment of the treating physician. Bacteria were cultured using standard microbiological methods.

The Center for Disease Control and Prevention criteria (CDC) for site-specific infections were used as standard definitions for HAls. ${ }^{7}$ Infections that occurred less than 48 hours after admission, or those that were present or 
incubating at the time of admission, were not regarded as nosocomial.

All suspected cases were discussed between haematologists and the infection control team. The aims of these meetings were first, to reach a consensus on type of HAI, and second to identify preventable nature or not of the infection, dysfunctional healthcare procedures, and to decide about corrective measures. Types of HAls included in this particular study were mucocutaneous, pulmonary aspergillosis, bloodstream infections related to intravascular devices, pneumonia, primary bloodstream infections, urinary tract infections, gastrointestinal tract infections, bloodstream infections and nosocomial fever of unknown origin.

Nosocomial fever of unknown origin (FUO) was defined as fever of at least $38^{\circ} \mathrm{C}$ for more than 4 hours occurring on several occasions in a hospitalized patient in whom neither fever nor infection was present on admission and for which a cause cannot be determined after 3 days of investigation, including 2 days of cultures. ${ }^{8-10}$ Nosocomial FUO was counted as a $\mathrm{HAl}$ according to Ibrahim $\mathrm{KY}$ et al. ${ }^{4}$

\section{HAls rate calculations}

$\mathrm{HAI}$ rates measured during the surveillance period included the overall HAI attack rate (per 100 patients) and the incidence density rates of HAls (number of HAI cases divided by 1,000 patient-days and multiplied by 1,000 ). Patient-days are the total number of days that patients are hospitalized during the selected time period.$^{11}$

\section{Statistical analysis}

Statistical analysis of the pre-coded data was done using the Statistical Package for Social Science Program (SPSS, Version 10; IBM, Armonk NY). The first part of the analysis examined the entire cohort of patients. In this section, we described the overall population; categorical variables were expressed as count and percentage. Continuous variables were expressed as mean and standard deviation (SD) or median and interquartile range. Also we calculated the overall $\mathrm{HAl}$ attack rate of HAls in this unit and the incidence density of HAIs, as well as clinical and microbiological patterns of HAls.
The second section of results is the analytic part in which we compared outcomes between patients with HAls and with those who did not develop HAls. We used the chi-squared test for comparing mortality rates and the Student t-test for comparing length of hospital stay. The second objective of this part was to identify risk factors of HAls. First we used bivariate analysis to identify potential factors associated with HAl's; the Student t-test was used for comparing quantitative variables, while the chi-squared test was used for qualitative variables. The significance level was set at a $p<0.05$. Variables identified as potential risk factors by the bivariate analysis with a $p$ value $<0.2$ were included in an unconditional logistic regression. Variables were introduced into the multivariate analysis in a stepwise manner to construct the final model. The condensed model was presented with crude odds ratio $(\mathrm{OR})$ and $95 \%$ confidence interval $(\mathrm{Cl})$. The significance level was set at a $p<0.05$

\section{Ethics statement}

The collected data remain strictly confidential. Our research protocol did not harm patients' health, safety, or privacy. This study was approved by our institution ethics committee.

\section{Results}

A total of 150 patients was included in the study. Patient characteristics are presented in Table I.

Among the 150 patients, 49 developed 58 HAls. The overall HAl attack rate was 32.6/100 patients with an incidence of 15.7 per 1000 patient-days at risk. The majority of patients developed only one HAI, seven patients developed two HAls, and one patient developed three HAls. Concerning the patients' diagnosis, the highest incidence rate of HAls was observed in patients with acute myeloid leukaemia (53.57/100 patients), followed by non-Hodgkin's lymphoma (35.71/100 patients), acute lymphoblastic leukaemia (28.75/100 patients), and Hodgkin's lymphoma (10.0/100 patients).

Among the 58 HAls, nosocomial FUO was the most frequent infection $(42.9 \%$ of total HAls), followed by mucocutaneous infections and pulmonary aspergillosis. Table II summarizes rates of specific infections. 
Table I. Patients characteristics at admission

\section{Variables}

Mean \pm SD n (\%)

Age (Years)

$23.1 \pm 18,3$

\section{Gender}

Male

Female

\section{Mode of admission}

Scheduled admission

107(72.3)

Emergency

Transfer from another department or hospital

\section{Hospitalization sector}

Protective isolation

Conventional hospitalization

\section{Previous hospitalization}

$<3$ mois

3-6mois

None

\section{Haematological malignancies}

Acute Myeloid leukaemia

Acute Lymphoblastic Leukaemia

Non-Hodgkin's Lymphoma

Hodgkin's Lymphoma

Burkitt's Lymphoma

Others

\section{Underlying diseases}

\begin{tabular}{lr}
\hline Diabetes & $9(6.0)$ \\
Pulmonary aspergillosis & $5(3.3)$ \\
Mucositis & $11(7.4)$ \\
Antibiotics at admission $\mathbf{( \pm 4 8 h )}$ & $16(10.7)$ \\
\hline Neutropenia & $79(53)$ \\
\hline Immunodeficiency & $26(10.1)$ \\
\hline Medication usage &
\end{tabular}

Prolonged corticosteroids therapy

Recent corticosteroids therapy

Chemotherapy

Radiotherapy 
Table I. Patients characteristics at admission (continued)

\begin{tabular}{lr} 
Variables & Mean \pm SD n (\%) \\
\hline Exposure to invasive devices or procedures $\mathbf{n}(\%)$ & $137(91.3)$ \\
\hline Peripheral Venous Catheter & $2(1.3)$ \\
Central Venous Catheter & $12(8)$ \\
Implantable venous access port & $5(3.3)$ \\
Mechanical Ventilation & $7(4.7)$ \\
Urinary Catheter & $52(34.9)$ \\
Lumber puncture & $64(43.0)$ \\
Bone marrow aspiration & $7(4.7)$ \\
Bone marrow biopsy & \\
Routine blood test :Median [Q1-Q3] & $5.8[4.0-11.6]$ \\
\hline White blood cell $(\times 109 c e l l s / L)$ & $162[74.5-233.0]$ \\
Platelets $(\times 109$ cells/L) & $11.2[10.1-12.6]$ \\
Haemoglobin $(g / L)$ & $3.2[1.7-6.0]$ \\
Neutrophil granulocyte $(\times 109 c e l l s / L)$ & \\
Hospital Outcomes $\mathbf{n}(\%)$ & $20.9 \pm 18.2$ \\
\hline Median hospital days $[$ Mean $\pm S D]$ & $14(9.3)$ \\
Mortality $\mathbf{n}(\%)$ &
\end{tabular}

Table II. Characteristics of 58 HAls: site of infection, infection rate, and isolated pathogens

\begin{tabular}{|c|c|c|c|}
\hline Site of Infection & $\begin{array}{c}\text { No. (\% of total HAI's) } \\
\mathrm{N}=58 \\
\end{array}$ & $\begin{array}{l}\text { Specific incidences } \\
\text { (/100 exposed patient) }\end{array}$ & Isolated Pathogens (n) \\
\hline $\begin{array}{l}\text { Nosocomial Fever of } \\
\text { unknown origin }\end{array}$ & $21(42.9)$ & 26.58 & - \\
\hline $\begin{array}{l}\text { Mucocutaneous } \\
\text { infections }\end{array}$ & $8(16.3)$ & 5.33 & $\begin{array}{c}\text { Geotrichum capitatum (2) } \\
\text { Proteus mirabilis (1) } \\
\text { Escherichia coli (1) }\end{array}$ \\
\hline Pulmonary aspergillosis & $7(14.3)$ & 4.66 & Aspergillosis Antigen (2) \\
\hline $\begin{array}{l}\text { Bloodstream infections } \\
\text { related to intravascular } \\
\text { devices. }\end{array}$ & $6(12.2)$ & 4.10 & Klebsiella pneumoniae (1) \\
\hline Pneumonia & $6(12.2)$ & 4.00 & - \\
\hline $\begin{array}{l}\text { Gastro-intestinal system } \\
\text { infections }\end{array}$ & $5(10.2)$ & 3.33 & $\begin{array}{c}\text { Geotrichum capitatum (2) } \\
\text { Candida albicans (1) }\end{array}$ \\
\hline $\begin{array}{l}\text { Primary Bloodstream } \\
\text { infections }\end{array}$ & $4(8.2)$ & 2.66 & $\begin{array}{c}\text { Geotrichum capitatum (1) } \\
\text { Enterobacter cloacae (1) } \\
\text { Klebsiella pneumoniae (1) } \\
\text { Streptococcus pneumoniae (1) }\end{array}$ \\
\hline
\end{tabular}

Urinary tract infections

$1(2)$

14.28 
Only $24.1 \%$ of infections were laboratory documented (Table II). Geotrichum capitatum and Gram-negative bacteria were the most isolated pathogens $(41.66 \%$ each) followed by Streptococcus pneumoniae (8.3\%) and Candida albicans (8.3\%).

Concerning cases of Geotrichum capitatum, a total of 5 infections caused by this germ were recorded during June and the first week of July 2016: 2 mucocutaneous infections, 2 gastrointestinal infections, and 1 primary bloodstream infection. In 3 cases, HAls were associated with neutropenia, and in 2 cases patients died. Characteristics of these 5 cases are shown in Table III. Microbiological confirmation was performed by oral swabbing in mucocutaneous and gastrointestinal cases and by blood culture in primary bloodstream infection. Figure 1 shows an overlap between cases hospitalizations periods and suggests the same origin of this germ. After discussion of these cases we performed several samplings, including sampling of food which was prepared by a subcontracting company. Food samples were negative and we did not identify the source of this outbreak. No other cases were observed after this outbreak.

Concerning outcomes of HAls, there was no significant difference in mortality rates between patients with HAls and with those without HAls $(12.2 \%$ versus
Figure 1.

Synoptic table of Geotrichum capitatum outbreak

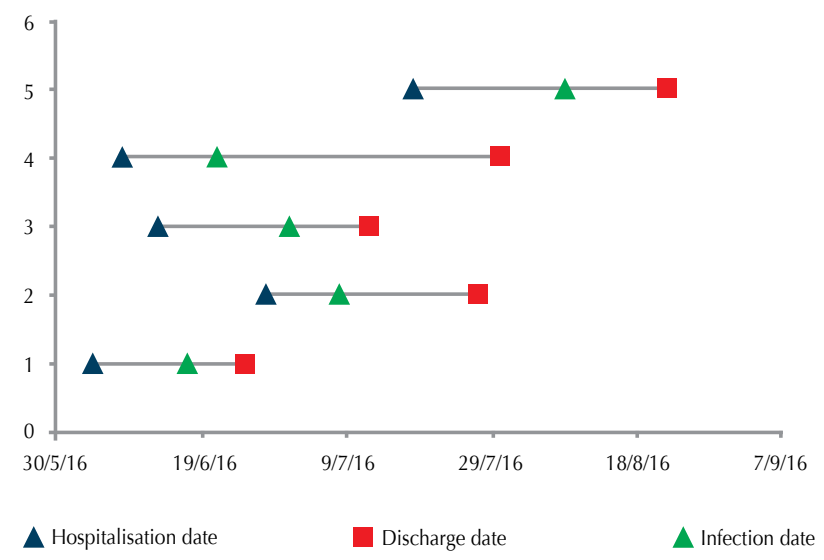

$7.9 \%, \mathrm{p}=0.57)$. In contrast, mean length of stay was significantly longer among patients with HAls than others $\left(31.8 \pm 17.9\right.$ days versus $15.5 \pm 15.9$ days, $\left.\mathrm{p}<10^{-3}\right)$ On bivariate analysis, factors significantly associated with HAls were admission from emergency $(p=0.03)$, duration of neutropenia $(p=0.035)$, recent corticosteroid therapy $(p=0.02)$, chemotherapy $(p=0.038)$, acute myeloid leukaemia $(p=0.009)$, aplasia inducing chemotherapy $\left(\mathrm{p}<10^{-3}\right)$, lumbar puncture $(p=0.02)$, bone marrow aspiration and biopsy $\left(p=10^{-3}\right)$, neutropenia $\left(p<10^{-3}\right)$, and duration of neutropenia $(p=0.019)$. Although not reaching statistical significance, male gender was associated with HAIs $(p=0.2)$.

Table III. General and clinical Characteristics of cases with HAls

\begin{tabular}{lccccccc} 
Case N & Gender & $\begin{array}{c}\text { Age } \\
\text { (years) }\end{array}$ & $\begin{array}{c}\text { Neutrophil } \\
\text { granulocyte } \\
\text { at admission } \\
\text { (Cells/mm3) }\end{array}$ & $\begin{array}{c}\text { Hematological } \\
\text { diagnosis }\end{array}$ & Type of HAl & Treatment & Death \\
\hline $\mathbf{1}$ & Male & 34 & 1640 & $\begin{array}{c}\text { Acute Lymphoblastic } \\
\text { Leukemia }\end{array}$ & $\begin{array}{c}\text { Gastro- } \\
\text { intestinal system } \\
\text { infections }\end{array}$ & Amphotericin B & Yes \\
\hline $\mathbf{2}$ & Female & 46 & 152 & $\begin{array}{c}\text { Acute Lymphoblastic } \\
\text { Leukemia }\end{array}$ & $\begin{array}{c}\text { Mucocutaneous } \\
\text { infections }\end{array}$ & Amphotericin B & No \\
\hline $\mathbf{3}$ & Female & 32 & 112 & $\begin{array}{c}\text { Acute Lymphoblastic } \\
\text { Leukemia }\end{array}$ & $\begin{array}{c}\text { Primary } \\
\text { Bloodstream } \\
\text { infections }\end{array}$ & $\begin{array}{c}\text { Voriconazole }+ \\
\text { Amphotericin B }\end{array}$ & Yes \\
\hline $\mathbf{4}$ & Female & 62 & 0 & $\begin{array}{c}\text { Acute Lymphoblastic } \\
\text { Leukemia }\end{array}$ & $\begin{array}{c}\text { Gastro- } \\
\text { intestinal system } \\
\text { infections }\end{array}$ & $\begin{array}{c}\text { Voriconazole }+ \\
\text { Amphotericin B }\end{array}$ & No \\
\hline $\mathbf{5}$ & Male & 41 & 1225 & Acute Lymphoblastic & $\begin{array}{c}\text { Mucocutaneous } \\
\text { Leukemia } \\
\text { infections }\end{array}$ & Amphotericin B & No
\end{tabular}


Table IV shows that after logistic regression, independent risk factors for developing HAls were male gender $\left(\mathrm{OR}[\mathrm{Cl}]_{95 \%} 4.60\right.$ [1.43-14.61]; $\left.\mathrm{p}=0.01\right)$, neutropenia $\left(\mathrm{OR}[\mathrm{Cl}]_{95 \%}\right.$ 10.20[2.26-45.72], $\left.\mathrm{p}=0.002\right)$, aplasia inducing chemotherapy $(\mathrm{OR}[\mathrm{Cl}] 6.0$ [1.0733.19], $\mathrm{p}=0.004)$ and bone marrow aspiration and biopsy $\left(\mathrm{OR}[\mathrm{Cl}]_{95 \%} 3.0\right.$ [1.10-8.03], $\left.\mathrm{p}=0.03\right)$.

\section{Discussion}

The primary objective of this prospective study was to determine the incidence of HAls in a haematologyoncology department and to identify their risk factors. We showed that HAls are a significant problem in the haematology-oncology ward of our hospital.

Table IV. Risk factors of HAls in hematology-oncology department

\section{Bivariate analysis}

\begin{tabular}{|c|c|c|c|c|}
\hline & OR $[95 \% \mathrm{CI}]$ & $\mathbf{P}^{*}$ & OR $[95 \% \mathrm{CI}]$ & P* \\
\hline Male gender & $1.64[0.75-3.39]$ & 0.21 & $4.60[1.43-14.61]$ & 0.01 \\
\hline Age & 1.01 [0.99-1.03] & 0.24 & & \\
\hline $\begin{array}{l}\text { Sector of hospitalization } \\
\text { (Conventional /Protective } \\
\text { isolation) }\end{array}$ & $1.53[0.78-3.14]$ & 0.22 & - & - \\
\hline
\end{tabular}

\begin{tabular}{|c|c|c|c|c|}
\hline $\begin{array}{l}\text { Mode of admission } \\
\text { (emergency/scheduled } \\
\text { admission) }\end{array}$ & $0.37[0.15-0.92]$ & 0.03 & - & - \\
\hline Prior hospitalization & $0.54[0.25-1.16]$ & 0.11 & - & - \\
\hline $\begin{array}{l}\text { History of pulmonary } \\
\text { aspergillosis }\end{array}$ & $1.41[0.22-8.6]$ & 0.72 & - & - \\
\hline History of diabetes & $1.70[0.43-6.66]$ & 0.43 & - & - \\
\hline Acute Myeloid leukemia & 2.98 [1.28-6.92] & 0.009 & - & - \\
\hline $\begin{array}{l}\text { Acute Lymphoblastic } \\
\text { Leukemia }\end{array}$ & 0.68 [0.344-1.35] & 0.27 & - & - \\
\hline $\begin{array}{l}\text { Neutropenia (neutrophils } \\
<500 / \mathrm{mm}^{3} \text { ) }\end{array}$ & $12.74[4.94-32.8]$ & $10-3$ & $10.20[2.26-45.72]$ & 0.002 \\
\hline Duration of neutropenia & 1.05 [1.004-1.113] & 0.035 & - & - \\
\hline $\begin{array}{l}\text { Antibiotherapy at } \\
\text { admission ( } \pm 48 \text { hours) }\end{array}$ & $1.70[59-4.88]$ & 0.31 & - & - \\
\hline $\begin{array}{l}\text { Recent corticosteroids } \\
\text { therapy }\end{array}$ & $2.24[1.11-4.5]$ & 0.02 & - & - \\
\hline Chemotherapy & $4.40[0.97-20.07]$ & 0.038 & - & - \\
\hline $\begin{array}{l}\text { Duration of } \\
\text { chemotherapy }\end{array}$ & 1.01 [0.99-1.028] & 0.28 & - & - \\
\hline $\begin{array}{l}\text { Aplasia inducing } \\
\text { chemotherapy }\end{array}$ & 24.15 [5.5-106.13] & $10-3$ & $6.0[1.07-33.19]$ & 0.04 \\
\hline Lumber puncture & $2.28[1.12-4.65]$ & 0.02 & - & - \\
\hline $\begin{array}{l}\text { Bone marrow aspiration } \\
\text { and biopsy }\end{array}$ & $3.28[1.6-6.7]$ & $10-3$ & $3.0[1.10-8.03]$ & 0.03 \\
\hline $\begin{array}{l}\text { Implantable venous } \\
\text { access port }\end{array}$ & $0.65[0.1-2.5]$ & 0.55 & - & - \\
\hline
\end{tabular}


The overall HAI attack rate of HAls in this unit was 32.6/100 patients with an incidence 15.7 per 1000 patient-days at risk. A higher incidence was reported in several studies. A prospective surveillance study performed in a haematology-oncology unit in Athens, Greece, ${ }^{12}$ revealed an incidence of 17.3 HAls per 1,000 patient-days. Also, in a 6-year prospective surveillance in a French haematology department, the HAls attack rate was 31.4 per 100 patients with an incidence of 18.2 per 1000 patient-days at risk. ${ }^{6}$ This rate reached 21.52 per patient-days in a recent Chinese study. ${ }^{13}$ However, lower incidences (4.7 per 100 patients) were reported in a Mexican study. ${ }^{1}$ Several factors may contribute to these differences in estimating HAls incidence in haematology-oncology departments, including the sample size, the length of study, the inclusion criteria, the data collection methods as well as the definition of HAls in the studied population. Moreover, the infection control and healthcare care practices, the type of ICU and the country income level may affect the rate of HAls in different studies.

As far as HAl types are concerned, nosocomial FUO was the most frequent $\mathrm{HAI}$ in our study and all cases were neutropenic. It is in agreement with several other studies which reported a high incidence of nosocomial FUO reaching up to 50\% in hematology/oncology. ${ }^{14-16}$ Viral infections may be among the pathogens responsible for FUO in these patients, but we did not screen for viruses because of lack of resources. The high rate of these infections can be explained by several factors: due to the severity and high mortality of infections in this population of patients, prompt empiric therapy is necessary. Therefore, for many febrile episodes, the infectious etiology cannot be established before antimicrobial therapy is initiated. Moreover, diagnosis of infections in neutropenic patients often is impeded, because of the diminished inflammatory response and often muted clinical signs. ${ }^{9}$

We did observe different HAI attack rates among patients with haematologic malignancies originating from different lineages. The highest attack rate was observed in acute myeloid leukemia indicating variability in each patient's vulnerability to nosocomial infections. This result was in line with those found in literature. ${ }^{3,13,17,18}$ The differences in the immunological and biological mechanisms of the myeloid neoplasm lineages may affect the vulnerability to HAI. In myeloid neoplasms, differentiation and maturation of myeloid stem cells (neutrophils, macrophages, and megakaryocytes) is impaired. ${ }^{19}$ In lymphoid neoplasms, fewer mature T/NK and B-cells, and a reduced adaptive immune-response are usually observed, however the innate system remains relatively intact to protect against HAls. ${ }^{13}$

HAls were mostly clinically documented in our study; this is in line with some other studies. 12,20,21 This could be explained by the fact that doctors prefer early empirical therapy over microbiological confirmation of infections. ${ }^{15}$ However, appropriate antibiotic therapy should be preceded by laboratory confirmation of pathogens and according to antibiogram.

During this surveillance, we recorded an unusual increase in positive cases of fungal infections caused by Geotrichum capitatum (5 HAls) during June and the first week of July 2016. Infections caused by Geotrichum capitatum are uncommon, and have been exclusively reported in immunocompromised patients. ${ }^{22}$ They mainly present as septicaemia with occasionally secondary localization..$^{23}$ Unfortunately, after investigation, we did not find a source of this germ. Gram negative bacteria were isolated in $41.66 \%$ of cases, The predominance of these organisms was frequently reported in similar populations; ${ }^{4,24}$ this might be due to the use of less cytotoxic chemotherapy that includes less severe mucositis and less profound neutropenia or the failure to perform routine prophylaxis against Gram-negative bacteria.

Independent risk factors for developing HAls were male gender, neutropenia, aplasia inducing chemotherapy and bone marrow aspiration and biopsy. Gender differences are a known contributory factor in the susceptibility to infection. ${ }^{25}$ Different bacterial species may elicit opposite responses among the sexes. Males usually generate a more aggressive inflammatory immune response to microbial stimuli with a higher mortality rate whereas females showed more protective immune and humoral responses. ${ }^{26}$ Clinically, male gender was shown as an independent risk factor for the development of nosocomial bloodstream infection. ${ }^{24}$ 
Neutropenia was revealed as a risk factor of HAls in our study, this goes hand in hand with Hui Liu et al. ${ }^{13}$ and Biswal et al. ${ }^{17}$ who found that neutropenia increases risk of nosocomial infections in haematology ward. Previous studies have demonstrated that neutropenia usually occurs during the first course of induction chemotherapy ${ }^{17}$ and this increases the risk of infections among patients undertaking induction chemotherapy. Severity of infection in patients with haematological malignancies is related directly to the degree and duration of neutropenia. ${ }^{27}$ Neutrophils are the first line of defence against bacteria and fungi. Lack of circulating neutrophils has a detrimental effect on the integrity of the normal human skin and mucosa, which are at great risk of invasive infection due to the colonizing bacteria, viruses and fungi as neutropenia impairs the phagocytic activity of the neutrophils. ${ }^{17}$ This supports the role of neutropenia as a risk factor predisposing to HAls and necessitates more careful management with strict application of infection control measures for this group of patients. ${ }^{14}$

We found that aplasia inducing chemotherapy was a risk factor of HAls. It is well established that chemotherapy is very likely to weaken the immune system as chemotherapeutic drugs can cause damage to the bone marrow, and they lead to the interference to the production of sufficient red blood cells, white blood cells, and platelets. Hence, chemotherapy is associated with more HAls. ${ }^{18}$ One study showed that the first course of induction chemotherapy is the stage when HAls are most likely to occur. ${ }^{17}$ Induction chemotherapy consists of a combination of myelosuppressive drugs and results in neutropenia in the majority of patients. As a consequence of severe leukaemia, a severe thrombocytopenia can be observed. Knowing the vital role in inflammation and immune response of platelets, the first course of chemotherapy is a predisposing factor for infections. Subsequently, as patients progress through the chemotherapy regimen, platelets counts increase, and their risks of developing HAls decrease. ${ }^{18}$

Bone marrow aspiration and biopsy increased risk of HAls in our sample. In patients with haematological disease, bone marrow aspiration is an important diagnostic tool. ${ }^{28}$ Although some hazards are recognized, in general, bone marrow aspiration and biopsy are thought to be safe procedures.
Infection is uncommon and generally less serious than haemorrhage. This access act as a foreign body, causing inflammation at the insertion site, resulting in decreasing of local anti-infection defence due to neutropenia and defective neutrophil function, allowing infections established from small inoculants. Secondly, haemorrhage is a common complication of bone marrow biopsy, in some cases, a haematoma can develop which becomes infected. Patients exposed to bone marrow biopsy in our sample have been probably exposed to an infected haematoma. This adverse event caused by bone marrow biopsy might be counted as a cutaneous infection in our study or even a nosocomial fever of unknown origin. In literature, a prospective study conducted on patients receiving intensive induction chemotherapy in a haematology ward found that bone marrow aspiration and biopsy were associated to higher risk of HAls. ${ }^{17}$ Excluding this study, literature reports that the most frequent adverse event of bone marrow aspiration is haemorrhage. ${ }^{28,29}$ Considering this fact, our result should be interpreted with caution; severity of illnesses, biological patterns and patients' outcomes could amplify the risk of HAls in patients who were exposed to bone marrow aspiration.

\section{Strengths and limitations}

The strength of our study includes the prospective inclusion of consecutive patients using standardized case definitions. Moreover, the true incidence was assessed because all patients were followed until their discharge. We also analyzed both intrinsic and extrinsic factors associated with HAl, which can help to reduce their incidence as well as to develop surveillance programs.

There are a few limitations in our study: first, the short study period and scarce episodes of HAls observed; second, no post-discharge surveillance was undertaken, which could have led to underestimation of the incidence because infections with long incubation periods could have been missed; and third, this study was a single-centre study, with all of the recruited patients from a university teaching hospital, thus the generalisability of our findings to other medical settings cannot be assumed.

The issue of considering the fever of unknown origin as $\mathrm{HAl}$ in patients with cancer is controversial in literature. Fever can be the only sign of infection within these 
patients in $36 \%$ of cases. ${ }^{8}$ Furthermore, viral or fungal infections cannot be identified in our laboratory; even bacteriological infections can be missed due to use of broad spectrum antibiotics. On the other hand, some of these cases might not have been due to infection. Fever can be attributed to cancer itself or to the treatment (e.g. chemotherapy, radiotherapy, immunosuppressive therapy) without infection.

Finally, we used logistic regression to identify the relevant factors associated with HAls, but this analytical method did not take into account of the possibility of changes in these factors over time. This potential drawback could be resolved by using other statistical methods, such as a proportional hazards model which considers the risks of event change over time. Despite those limitations, our findings provide health care workers with information about the burden of HAls that will facilitate informed decisions and the implementation of evidence-based preventive strategies.

\section{Conclusion}

Our study highlights the burden of HAls in our haematology-oncology department and the role of surveillance for specific HAls and analyzing its risk factors. A comprehensive education program focused on evidence-based approaches for all healthcare workers should be implemented in this unit. Moreover, adequate cleaning of the environment; precaution measures during construction works; monitoring of air and water for moulds; instructions for patients, and visitors; and special preparation of nutrition, should be more effective. Continuing active surveillance program is crucial to reduce the consequences of HAls, to improve patient safety and to evaluate effectiveness of these prevention measures.

\section{Competing interests:}

The authors declare that they have no competing interests.

\section{Acknowledgement}

We would like to appreciate and thank all those who have helped us during our research work.

\section{References}

1. Cornejo-Juárez, Vilar-Compte D, García-Horton A, LópezVelázquez $M$, Ñamendys-Silva $S$, Volkow-Fernández P. Hospital-acquired infections at an oncological intensive care cancer unit: differences between solid and hematological cancer patients. BMC Infect Dis 2016; 16(1). https://doi.org/10.1186/s12879-016-1592-1

2. Urrea M, Rives S, Cruz O, Navarro A, José García J, Estella J. Nosocomial infections among pediatric hematology/ oncology patients: Results of a prospective incidence study. Am J Infect Control 2004; 32(4): 205-208. https://doi.org/10.1016/j.ajic.2003.10.013

3. Huoi C, Vanhems $P$, Nicolle $M-C$, Michallet $M$, Bénet T. Incidence of Hospital-acquired pneumonia, bacteraemia and urinary tract infections in patients with haematological malignancies, 2004-2010: A Surveillance-Based Study. PLOS ONE 2013; 8(3): e58121. https://doi.org/10.1371/journal.pone.0058121

4. Ibrahim KY, Pierrotti LC, Freire MP, et al. Health care-associated infections in hematology-oncology patients with neutropenia: A method of surveillance. Am J Infect Control 2013; 41(11): 1131-1133. https://doi.org/10.1016/j.ajic.2013.03.299

5. Bouafia N, Bougmiza I, Bahri F, Letaief M, Astagneau P, Njah $M$. Ampleur et impact des évènements indésirables graves liés aux soins: étude d'incidence dans un hôpital du Centre-Est tunisien. Pan Afr Med / 2013. http://www.panafrican-medjournal.com/content/article/16/68/full/. [Accessed March 8, 2018]

6. Bow EJ, Rotstein C, Noskin GA, et al. A randomized, openlabel, multicenter comparative study of the efficacy and safety of piperacillin-tazobactam and cefepime for the empirical treatment of febrile neutropenic episodes in patients with hematologic malignancies. Clin Infect Dis Off Publ Infect Dis Soc Am 2006; 43(4): 447-459. https://doi.org/10.1086/505393

7. Horan TC, Andrus $M$, Dudeck MA. CDC/NHSN surveillance definition of health care-associated infection and criteria for specific types of infections in the acute care setting. Am J Infect Control 2008; 36(5): 309-332. https://doi.org/10.1016/j.ajic.2008.03.002

8. Durack DT, Street AC. Fever of unknown origin--reexamined and redefined. Curr Clin Top Infect Dis 1991; 11: 35-51. https://www.ncbi.nlm.nih.gov/pubmed/1651090. [Accessed March 8, 2018]

9. Hughes WT, Armstrong D, Bodey GP, et al. 1997 guidelines for the use of antimicrobial agents in neutropenic patients with unexplained fever. Infectious Diseases Society of America. Clin Infect Dis Off Publ Infect Dis Soc Am 1997; 25(3): 551573. https://doi.org/10.1086/513764

10. Unger M, Karanikas G, Kerschbaumer A, Winkler S, Aletaha D. Fever of unknown origin (FUO) revised. Wien Klin Wochenschr 2016; 128(21): 796-801. https://doi.org/10.1007/s00508-016-1083-9

11. National Nosocomial Infections Surveillance (NNIS) System Report, Data Summary from October 1986-April 1998, Issued June 1998 - American Journal of Infection Control. http://www.ajicjournal.org/article/S0196-6553(98)70026-4/ abstract. [Accessed March 8, 2018] 
12. Kafazi A, Stylianou C, Zwmas A, et al. Surveillance of Healthcare-Associated Infections Rates in HematologyOncology Patients. J Integr Oncol 2017; 6(4): 1-7. https://doi.org/10.4172/2329-6771.1000200

13. Liu $\mathrm{H}$, Zhao J, Xing $\mathrm{Y}$, et al. Nosocomial Infection in Adult Admissions with Hematological Malignancies Originating from Different Lineages: A Prospective Observational Study. Mills K, editor. PLOS ONE 2014; 9(11): e113506. https://doi.org/10.18282/amor.v3.is1.211

14. Al-Tonbary YA, Soliman OE, Sarhan MM, et al. Nosocomial infections and fever of unknown origin in pediatric hematology/oncology unit: a retrospective annual study. World J Pediatr WJP 2011; 7(1): 60-64. https://doi.org/10.1007/s12519-010-0212-1

15. Engelhart $S$, Glasmacher A, Exner $M$, Kramer $M H$. Surveillance for nosocomial infections and fever of unknown origin among adult hematology-oncology patients. Infect Control Hosp Epidemiol 2002; 23(05): 244-8. https://doi.org/10.1086/502043

16. Lamchahab M, Cherkaoui S, Ouhaddouss M, Qachouh M, Benchekroun S, Quessar A. Surveillance of healthcare associated infection in the adult hematology unit. Blood 2012; 120(21): 4712-4712.

17. Biswal S, Godnaik C. Incidence and management of infections in patients with acute leukemia following chemotherapy in general wards. Ecancermedicalscience 2013; 7. https:// doi.org/ 10.3332/ecancer.2013.310

18. Liu Y, Yan T, Wang J, Chan CW, Leung DY, Wang S. Healthcare-associated infections among patients with different types of acute leukemia in China: A surveillancebased study. Adv Mod Oncol Res 2017; 3(s1): 79-88. https://doi.org/10.18282/amor.v3.is1.211

19. Harris NL, Jaffe ES, Diebold J, et al. World Health Organization classification of neoplastic diseases of the hematopoietic and lymphoid tissues: report of the Clinical Advisory Committee meeting-Airlie House, Virginia, November 1997. J Clin Oncol 1999; 17(12): 3835-3849. https://doi.org/10.1200/JCO.1999.17.12.3835

20. Taj M, Farzana T, Shah T, Maqsood S, Ahmed SS, Shamsi TS. Clinical and microbiological profile of pathogens in febrile neutropenia in hematological malignancies: a single center prospective analysis. Journal of Oncology 2015; 2015: 1-5. https://doi.org/10.1155/2015/596504
21. Yadegarynia D, Fatemi $A$, Mahdizadeh $M$, Kabiri Movahhed R, Alizadeh MA. Current spectrum of bacterial infections in patients with nosocomial fever and neutropenia. Casp J Intern Med. 2013; 4(3): 698-701. https://www.ncbi.nlm.nih.gov/pmc/articles/PMC3755838/. [Accessed March 8, 2018]

22. Saghrouni F, Abdeljelil JB, Youssef YB, et al. Geotrichum capitatum septicemia in patients with acute myeloid leukemia. Report of three cases. Med Mycol Case Rep 2012; 1(1): 8890. https://doi.org/10.1016/j.mmcr.2012.09.003

23. Chittick P, Palavecino EL, Delashmitt B, Evans J, Peacock JE. Case of fatal blastoschizomyces capitatus infection occurring in a patient receiving empiric micafungin therapy. Antimicrob Agents Chemother 2009; 53(12): 5306-5307. https://doi.org/10.1128/AAC.00710-09

24. Samonis G, Vardakas KZ, Maraki S, et al. A prospective study of characteristics and outcomes of bacteremia in patients with solid organ or hematologic malignancies. Support Care Cancer 2013; 21(9): 2521-2526. https://doi.org/10.1007/s00520-013-1816-5

25. Marriott I, Huet-Hudson YM. Sexual dimorphism in innate immune responses to infectious organisms. Immunol Res 2006; 34(3): 177-192. https://doi.org/10.1385/IR:34:3:177

26. Humphreys H, Fitzpatick F, Harvey BJ. Gender differences in rates of carriage and bloodstream infection caused by methicillin-resistant Staphylococcus aureus: are they real, do they matter and why? Clin Infect Dis 2015; 61(11): 17081714.

27. Khayr W, Haddad RY, Noor SA. Infections in hematological malignancies. Dis--Mon DM 2012; 58(4): 239-249. https://doi.org/10.1016/j.disamonth.2012.01.001

28. Martí J, Antón E, Valentí C. Complications of bone marrow biopsy. Br J Haematol 2004; 124(4): 557-558. https://doi.org/10.1046/j.1365-2141.2003.04799.x

29. Bain BJ. Bone marrow biopsy morbidity: review of 2003. J Clin Pathol. 2005; 58(4): 406-408. https://doi.org/10.1136/jcp.2004.022178 